\title{
Bridging in-class participation with innovative instruction: use and implications in a Turkish university classroom
}

\section{Kadire Zeynep Girgin \& Dannelle D. Stevens}

To cite this article: Kadire Zeynep Girgin \& Dannelle D. Stevens (2005) Bridging in-class participation with innovative instruction: use and implications in a Turkish university classroom, Innovations in Education and Teaching International, 42:1, 93-106, DOI: 10.1080/14703290500049059

To link to this article: https://doi.org/10.1080/14703290500049059

$$
\text { 曲 Published online: } 17 \text { Feb } 2007 .
$$

\section{Submit your article to this journal $\longleftarrow$}

Џlll Article views: 134

Citing articles: 11 View citing articles $[7$ 


\title{
Bridging in-class participation with innovative instruction: use and implications in a Turkish university classroom
}

\author{
Kadire Zeynep Girgin ${ }^{\mathrm{a} *}$ and Dannelle D. Stevens ${ }^{\mathrm{b}}$ \\ ${ }^{\mathrm{a}}$ Bilkent University, Turkey; ${ }^{\mathrm{b}}$ Portland State University, USA
}

Student-centred university classrooms not only support student learning but also provide a forum to practise the skills of democratic participation, a particularly important set of skills for citizens in young democracies like Turkey where this study takes place. Yet, often classroom assessment methods do not match these innovative teaching methods and, therefore, do not encourage students to increase and learn from their participation. This paper describes how two professors bridged innovative classroom instruction and student participation through the use of a detailed, written description of in-class participation. They document the changes in their classroom practices and the student responses to these innovations and assessments.

\section{Introduction}

Many have called for more student-centred university classrooms (Angelo, 1999; Finkel, 2000). Social constructivists state student-centred classrooms involve discussion, critical analysis and group work, whereas teacher-centred classrooms focus more on lecture and recitation (Good \& Brophy, 1995). Student-centred classrooms increase student motivation as well as 'deep' instead of 'surface' learning (Brooks, 1990; Dole \& Sinatra, 1998; Biggs, 1999). In addition, an often-overlooked advantage is that student-centred classrooms give students the opportunity to practise the skills of democratic citizenship. While Brookfield and Preskill believe that 'lecture is often necessary to introduce difficult ideas and to model critical inquiry' (1999, p. xiii), discussion remains an 'indispensable part of democratic education' (1999, p. 20). Furthermore, 'Discussion and democracy are inseparable because both have the same root purpose- to nurture and promote human growth' $(1999$, p. 4).

To build the foundation for democratic skills, there is a need for more specific information on not only how to create student-centred classrooms but also how to link the assessment system to those new methods (Boud, 1990). Boud argues that when our assessment system does not match our methods, we create a 'gap between what we encourage students to focus upon

*Corresponding author. Faculty of Business Administration, Bilkent University, Ankara 06800, Turkey. Email: zgirgin@bilkent.edu.tr 
(through our classroom practices) and what is needed for meaningful learning to occur' (1990, p. 2).

This study takes place at a private Turkish university where students are not generally exposed to or accustomed to student-centred learning (Stevens \& Girgin, 2001, 2002). The Turkish elementary and high school system is dominated by rote learning and memorisation (Günçer, 1998). There is a need for students to have a place to express their ideas and subject them to public scrutiny. Therefore, in a transitional society like Turkey, where democracy is still young, students need all the practice they can get in expressing their ideas, listening to dissenting opinions and being held accountable for their beliefs.

The purpose of this paper is to describe and evaluate a student-centred innovation in a Turkish university classroom. In particular this paper elaborates:

1. A way to change assessment practices by including a written description of in-class participation (ICP).

2. A set of student-centred activities.

3. Student responses to these student-centred classrooms and assessment practices.

\section{Background}

In this section, we explain three reasons for more student-centred practices, namely democratic participation, constructivist learning theory and student preferences.

\section{Democratic participation}

Student-centred classrooms where discussion, debate and critical analysis are practised build the skills necessary to participate in a democracy. Brookfield and Preskill (1999) believe that, when students practise dialogue and conversation, they learn how to suspend judgement, discuss ideas and come to an informed decision. These are foundational skills for democratic citizens. They moreover state:

Discussion is one of the best ways to nurture growth because it is premised on the idea that only through collaboration and co-operation with others can we be exposed to new points of view. This exposure increases our understanding and renews our motivation to continue learning. In the process, our democratic instincts are confirmed; by giving the floor to as many different participants as possible, a collective wisdom emerges that would have been impossible for any of the participants to achieve on their own. (Brookfield \& Preskill, 1999, p. 4)

Thus, increased classroom participation gives students a way to practise the skills of collaboration and co-operation, leading to increased tolerance for different ideas as well as clarification of their own. Discussion fosters the development of new ideas not possible to achieve by a single person. Changing our classroom practices might enhance our Turkish students' discussion and democratic citizenship skills.

\section{Constructivist learning theory}

Recent research on effective human learning underscores the value of 'constructing' meanings through active participation (Brooks, 1990; Dole \& Sinatra, 1998; Biggs, 1999). Based on Piaget 
and Vygotskian learning theories, constructivist activities mirror the way the mind gathers, assesses and retains information. Burns et al. (1991) found that students retained more when the classes were student-centred, i.e. students had more opportunities for research and discussion in a less competitive atmosphere.

\section{Student preferences}

Finally, another reason to create student-centred classrooms is that students themselves generally prefer them. Williams found that 'preferences for student-centred learning, characterised by a shift from lecturers as expert sources of knowledge to a facilitative role, exist in $72 \%$ of the sample' (1992, p. 1). In this study, $76 \%$ felt that classroom discussion furthered understanding, although some wanted the professor to lecture sometimes. However, they said they learned more when they were asked to discuss in class.

Above we explain our three reasons for creating student-centred classrooms in Turkey. However, to boost the effect of a more student-centred classroom our assessment system should match our practices. In the next section we describe why and how we developed our ICP assessment and the activities we use to foster a student-centred classroom.

\section{Development of in-class participation assessment}

Students pay attention to what they are graded on (Elton \& Laurillard, 1979; Boud, 1990; Angelo, 1999). Biggs confirms that 'What and how students learn depends to a major extent on how they think they will be assessed' $(1999$, p. 141). Students approach learning depending on the nature of the assessment (Ramsden, 1988). Thus, if we wanted to initiate student-centred instructional practices, we needed to have an assessment system that matched these classroom activities.

Moreover, Turkish students are not accustomed to discussion in class and other active and interactive methods. In fact, during their schooling, we argue that few, if any, Turkish students have experienced student-centred classrooms. They are more accustomed to teaching that is based on the transmission: teacher as the authoritative source of expert knowledge passes on a fixed body of information to be practised alone and reproduced by students on demand. One primary reason for this well-established model to subsist is that Turkish students and schools prepare for a highly competitive, nationally administered university entrance examination using a rigid national curriculum. Our evidence is based on our own experiences. Over her lifetime, Zeynep has mostly been educated in Turkey. From 2000 to 2002, Dannelle was a teacher educator who observed over 200 lessons in Turkish elementary and high schools. Both authors found that in most Turkish classrooms there is little room for dissent, discussion and debate. Our other research in progress indicates that most Turkish university students experience the same kind of teacher-centred classrooms. Yet we wanted our own classrooms to be student-centred.

We needed to find a way to bridge our classroom innovations and student participation. We wanted students to take our innovations seriously. Since assessment schemes give students information about where to allocate their energy and effort, we told students directly and specifically in writing what we expected in terms of classroom participation. We mainly used the following three methods to communicate to students the importance of ICP: 
1. Allocation of a percentage of final grade to ICP.

2. Distribution of written criteria sheets describing high levels of ICP.

3. Thorough class discussion of the criteria sheet for ICP.

\section{Allocation of a percentage of final grade to ICP}

Firstly, we allocated between 15 and $20 \%$ of final grade to ICP. This is not particularly unusual in Turkey. According to the survey we did on the online registration system (Table 1), instructors in the Faculty of Business Administration allocated between 5 and $20 \%$ of the final grade to ICP in around $40 \%$ of classes: $41 \%$ in Fall 2000, 38\% in Spring 2001, 35\% in Fall 2001, 39\% in Fall 2002 and 40\% in Spring 2003, with the exception of Spring 2002 when this fell to $28 \%$.

Although it might be argued that students are accustomed to receiving some portion of their grades from ICP, the important issue lies in how professors view and evaluate this activity. To many professors, ICP is a placeholder for attendance. Although it is common practice in Bilkent as well as in many of the other well-known universities in Turkey to allocate some percentage of the final grade to ICP, to our knowledge, to give students a prior, written description in such a way is completely unusual.

\section{Distribution of written criteria sheets describing high levels of ICP}

Secondly, to make it clear for students as well as ourselves what we understood about ICP and how we assessed it, we distributed a written description of ICP (Figure 1). It was written as a criteria sheet with detailed descriptors of appropriate behaviours that indicate that the student is participating. It could also be a self-evaluation tool for students who may be confused about how to participate.

As noted in Figure 1, our criteria sheet informed students about the definition of ICP and the criteria used to grade them. Our criteria fall into the following categories:

- Attendance.

- Doing the assigned readings.

Table 1. Number of undergraduate courses in the Faculty of Business Administration that allocate a percentage of the final grade to in-class participation (ICP)

\begin{tabular}{llccccr}
\hline \multicolumn{7}{c}{ No. of courses that allocated \% grade to ICP (percentage distribution } \\
given in parentheses) & \\
\cline { 2 - 6 } Term & $0 \%$ & $5 \%$ & $10 \%$ & $15 \%$ & $20 \%$ & Total \\
\hline Fall 2000 & $27(59)$ & $5(11)$ & $10(22)$ & $4(8)$ & $0(0)$ & $46(100)$ \\
Spring 2001 & $29(62)$ & $7(15)$ & $4(9)$ & $5(10)$ & $2(4)$ & $47(100)$ \\
Fall 2001 & $34(65)$ & $1(2)$ & $9(17)$ & $8(16)$ & $0(0)$ & $52(100)$ \\
Spring 2002 & $28(72)$ & $4(10)$ & $5(13)$ & $0(0)$ & $2(5)$ & $39(100)$ \\
Fall 2002 & $35(61)$ & $9(16)$ & $5(9)$ & $8(14)$ & $0(0)$ & $57(100)$ \\
Spring 2003 & $25(60)$ & $8(19)$ & $7(16)$ & $0(0)$ & $2(5)$ & $42(100)$ \\
\hline
\end{tabular}




\section{BILKENT UNIVERSITY}

Department of Management

Autumn 2000

MAN 201-Introduction to Business

Description of assessment: 'In-class Participation' (15\%)

For the purposes of this course, 'in-class participation' grade depends on:

Regular and on-time attendance to class, not missing any classes without an acceptable excuse (i.e. illness, of you or a family member, accident, moving houses, any expected and uncontrollable event), giving an advance notice of such a case, and not being late; Doing the assigned homework, i.e. reading the course material critically, doing some search in the library, etc.

Doing the above will help you to develop your responses as listed below, which will in turn effect your in-class participation grade positively. Therefore a student who demonstrates a 'high' level of 'in-class participation' does the following:

Listens-alert, eyes on the speaker, non-verbal signs of attention demonstrated;

Responds-answers questions when asked directly;

Volunteers - contributes to discussion, without being asked, takes notes;

Speaks - to the point being discussed;

Self-assesses—changes behaviour based on feedback from the lecturer and fellow

students;

Reflects-writes reflections during class and analyses own behaviour;

Participates - in activities with energy and evident enthusiasm;

Becomes a contributing group member who solves problems and fosters positive

communication;

Does not sit back and wait for directions;

Does not watch the clock and wait for the class to end;

Does not start getting ready to finish and leave the class before the lecturer says so.

Figure 1. Criteria sheet for the description of in-class participation assessment

- Classroom behaviours that communicate participation.

By putting the criteria into writing, we sought to avoid the 'moving targets' problem of vague assessment practices both for professors and students. We hoped that written criteria would breed more clarity and objectivity for us the professors. When we are more specific in defining our assessments, it is more likely that we will be consistent and reliable in our evaluation.

The reason why teachers in higher education vary in the marks they award the essays, is that they are using different criteria. Or, if they are using the same criteria, they are giving different weightings to them in terms of importance. There are good reasons for making criteria explicit: to be fair to the student. When you set a task or an assignment make clear the criteria on which it is assessed so the student can tailor his or her response to your assignment. (Brown et al., 1994)

It might be argued that, as did one of Zeynep's students mentioned below, in fact, there is no need to go into the details of defining ICP. The general belief is that students readily know that, if they raise their hands and actually speak up voluntarily - or involuntarily when the instructor asks - and look alert, then the professor will believe that they are participating at a high level. However, what we do know is that the clearer the expectations for the students, the more likely they will work to meet them (Ramsden, 1988; Boud, 1990). 


\section{Class discussion of the criteria sheet for ICP}

Thirdly, we answered all student questions regarding this criteria sheet. They could begin to see that not only were we allocating a percentage of the grade to ICP but we also had a written description of how we define our expectations. This is where it got interesting.

The first term we used the criteria sheet for ICP, we passed it out to three classes, three weeks into the semester. Zeynep taught 90 undergraduates in the 'Introduction to Management' classes in the Faculty of Business Administration. About three-quarters of this large group were second-year Management students and the rest were from various other departments and years who took the course as an elective. In this term Dannelle taught only four graduate students in a seminar on history teaching methods in the Graduate School of Education where she used the ICP description for the first time. In the second year, Dannelle used the criteria sheet in a class of 27 graduate students. There was a contrast between the responses of the undergraduate and graduate classes.

The undergraduate student responses indicated what students were accustomed to in Turkish university classrooms. Zeynep wrote the following e-mail message to Dannelle:

I distributed the sheets at the beginning of each class today (you know I have two sections of the same course), went over once again orally, and I got some interesting feedback. Two students said—for the ICP sheet, 'These are very obvious things. We are second year students and do not have to be reminded of these, and it is actually a waste of time going through all this!'

One other student's remark was about timing. When I said these criteria sheets might be considered as a contract between them and me and I commit myself to them until the end of the term, that student replied, 'Since you have only now distributed these 'contracts' and not before, they cannot be applied for the previous part of the term. Because a contract cannot be valid before it is accepted by all the parties involved'. Now, curious about his response and not wanting him to push me harder, I replied, 'I would have assessed and graded you on ICP according to these criteria whether or not I put the criteria down on paper and distributed them to you. These can be regarded as contracts and I will stick with them. Distributing criteria sheets is not the usual practice among your lecturers. They simply assume that you know about their criteria and work accordingly. The problem is that you as the students might have assumed other criteria and work differently.'

Aren't the two reactions different? They are like coming from two totally different groups of people.

When Dannelle distributed the criteria sheets, she asked students if they had ever seen anything like this before. Even though they replied 'no', they nevertheless liked the idea of a written description. All of Dannelle's students were studying to become Turkish high school teachers. Neither the first small group of four nor the subsequent 27 graduate students questioned the written ICP criteria sheets when handed out in class. This graduate programme is designed to infuse innovative teaching practices into the preparation programme of Turkish high school teachers. One might expect that these graduate students would be more open and responsive not only to student-centred classes but also to new assessment methods. In comparison to Zeynep's business undergraduates, none of these students saw this as a useless, time-consuming and almost childish way to handle assessment of ICP.

Through the three methods described above we communicated the importance of ICP. Yet it is not enough. We needed to use student-centred activities. In the next section we explain the various classroom practices we used to foster ICP. 


\section{Implementation of classroom practices to foster in-class participation}

During the term each of us used a variety of active learning and student-centred methods. These are summarised in Figure 2.

\section{Think-pair-share}

Even during a lecture, a professor can foster class discussion. Think-pair-share is a quick and powerful activity that gets all students talking. Students cannot avoid saying something when working in a pair. The professor asks a question to the whole class and, then, asks the class to think about it on their own for a minute. Then, pair up with the person next to them and discuss their answer to the question. Finally, students are asked to share their answers with the whole class.

\begin{tabular}{|c|c|c|c|}
\hline $\begin{array}{l}\text { Name of } \\
\text { activity }\end{array}$ & Description & Advantages & Time \\
\hline $\begin{array}{l}\text { Think-pair- } \\
\text { share }\end{array}$ & $\begin{array}{l}\text { Professor asks the class a question. } \\
\text { Students think about answer. } \\
\text { Students pair with neighbour to } \\
\text { discuss. } \\
\text { Then, share with whole class. }\end{array}$ & $\begin{array}{l}\text { Everyone has to } \\
\text { think and talk about } \\
\text { the question. }\end{array}$ & 5 minutes \\
\hline $\begin{array}{l}\text { Discussion } \\
\text { roles }\end{array}$ & $\begin{array}{l}\text { Students receive cards with } \\
\text { discussion roles. } \\
\text { Students practise new roles at least } \\
\text { once during the discussion. }\end{array}$ & $\begin{array}{l}\text { Students can see } \\
\text { there are a variety } \\
\text { of roles one can } \\
\text { play in a discussion. }\end{array}$ & $\begin{array}{l}20-60 \\
\text { minutes }\end{array}$ \\
\hline Fishbowl & $\begin{array}{l}\text { Inner circle (half class) discusses } \\
\text { topic. } \\
\text { Outer circle (other half) can pass } \\
\text { notes to inner circle to add } \\
\text { discussion points OR can be } \\
\text { observers documenting who is } \\
\text { speaking for how long and who } \\
\text { does not speak. }\end{array}$ & $\begin{array}{l}\text { Students can } \\
\text { observe how a } \\
\text { discussion works. }\end{array}$ & $\begin{array}{l}20 \text { minutes for } \\
\text { half; after } 20 \\
\text { minutes } \\
\text { switch circles }\end{array}$ \\
\hline Case studies & $\begin{array}{l}\text { Students read cases from the } \\
\text { textbook. } \\
\text { Students work in small groups of } \\
\text { three or four to discuss the case. } \\
\text { Whole class discussion follows. }\end{array}$ & $\begin{array}{l}\text { Students must read } \\
\text { the text and discuss } \\
\text { with their peers. } \\
\text { All get practice } \\
\text { talking. }\end{array}$ & $\begin{array}{l}50-60 \\
\text { minutes }\end{array}$ \\
\hline $\begin{array}{l}\text { Student } \\
\text { presentation } \\
\text { with class } \\
\text { discussion }\end{array}$ & $\begin{array}{l}\text { Students prepare a term paper in } \\
\text { pairs. } \\
\text { Students give class presentation. } \\
10 \% \text { of grade depends on class } \\
\text { discussion they generate. }\end{array}$ & $\begin{array}{l}\text { Students learn about } \\
\text { facilitation of } \\
\text { discussion on } \\
\text { content topic. }\end{array}$ & 15 minutes \\
\hline
\end{tabular}

Figure 2. Activities designed to foster in-class participation 


\section{Discussion roles}

It is almost inevitable that during class discussions usually the same students participate while others just listen. To address this problem, Dannelle made cards that describe 12 different roles, based on Brookfield and Preskill (1999). She hands these out to the students before the discussion and suggests that they practise this new behaviour once during the discussion. Six of the 12 roles are:

1. Question asker: Ask a question or make a comment that encourages someone else to elaborate on something that the person has said.

2. Body language mirror: Use body language (in a slightly exaggerated way) to show interest in what different speakers are saying.

3. Idea builder: Contribute something that builds on or springs from what someone else has said. Be explicit about the way you are building on the other person's thoughts.

4. Paraphraser: Make a comment that at least partly paraphrases a point someone has already made.

5. Appreciator: Find a way to express appreciation for the enlightenment you have gained from the discussion. Try to be specific about what it was that helped you understand something better.

6. Contrarian: Disagree with someone in a respectful and constructive way.

She uses these discussion role cards three times each term. Labelling the roles allows students to remember and practise the roles more quickly and easily. At the end of the discussion, she encourages the class to evaluate the quality of the discussion as well as the content.

\section{Fishbowl}

Students are divided into two groups. Half of the group forms a circle in the middle of the room and carries on the discussion. The other half places their desks outside the circle and can perform one of the two roles:

1. Quiet partners: write down comments and contributions to pass on to the inner circle.

2. Observers: keep track of who talks, who does not, what kind of contributions people make, etc.

\section{Discussion of short cases}

In business course books, there are short, mostly real-life cases. Zeynep asks the students to come to the classes having read each week's case(s). After covering the key concepts of the chapter (more in question and answer format than lecture), students discuss the case first in small groups of three or four people using the questions provided. Then the whole-class discussion follows. The small-group discussions provide even the quietest students with the opportunity of speaking and participation.

\section{Student presentations with class discussion}

In Zeynep's course, students do a presentation of their term project, which is a research paper done in pairs. Students are encouraged to foster a class discussion since $10 \%$ of their presenta- 
tion assessment depends on 'generating a good class discussion with your questions as well as answers'. From these presentations, students have the opportunity to practise such skills as analysing any knowledge presented critically, raising their voices, listening and presenting their opinions.

\section{Student responses to student-centred classrooms}

The above methods helped us foster ICP. However, how did our students respond to these methods? Our evidence comes from mid-term class evaluations, responses to the end-of-term quiz, and two items on the formal student course evaluations.

Our first evidence is from in-progress evaluations completed in the middle of the term. In this evaluation sheet (Figure 3), four open-ended, very broad questions are asked, one of which is 'what works in this class for you?' During Fall 2001 in Zeynep's 'Introduction to Business' course where the above-mentioned methods and tools were used, 64 students filled out the survey. Students stated various student-centred activities as the best working part of the course. Thirty-nine responses (61\%) indicated that it was 'discussions' and 20 as ICP. To quote one of

\section{BILKENT UNIVERSITY}

Department of Management

Fall 2000

MAN 201-Introduction to Business

\section{In-Progress Evaluation Form}

This in-term evaluation form is prepared to help you provide immediate feedback to the instructor and to allow a chance for modifications. The questions are to probe the teaching methodologies and open-ended. Evaluations are to be seen only by me, the instructor. I will process the evaluations, and discuss the summary results with you, the students, in the class as soon as possible. Please DO NOT put your names on the sheets, and DO NOT be afraid that what you write might cause you trouble. It will not. The only reason I do this is to be able to build a better learning environment for you as well as for myself.

1. What works in this class for you?

2. What does not work in this class for you?

3. What suggestions do you have to make it better for your learning?

4. What should I know about you as a learner that will help you learn better?

Figure 3. In-progress evaluation sheet 
the comments directly, a student wrote, 'it is as if the students carry out the classes'. Moreover 21 responses said that the positive class environment, open to discussion and voicing ideas and/ or questions, really worked well.

Dannelle also did the same in-progress mid-term evaluation in the larger class of 27 students. This class was called 'Guidance' and was designed to prepare students to work with the variety of typical and exceptional students in their future schools. Students had groupwork activities every day, were required to lead class discussions as well as conduct communication skills activities. In answer to the question, 'What works for you?', out of 23 surveys returned, 17 students (74\%) mentioned that one or all of the student-centred activities worked for them. Responses to this question included, 'everything', 'group-work', 'activities', 'communication skills' and 'discussion'. One student commented, 'I learned communication skills and the importance of communication. Students prepare activities such as communication skills and discussions. I learned how I can organise a discussion in the class'. The validity of the evaluations we carried out ourselves can be considered quite high because the survey specifically stated that students should not put their names and that their feedback would not cause any problems.

In addition to the in-progress evaluations, in her traditional end-of-term quiz, Zeynep asks this question 'Name three things done in this class to help you actively and better engage in learning this course'. The answers usually reveal the things students really like and remember from this class. The results of the class in Fall 2001 were also in support of in-class participation and discussion: 63 out of $83(76 \%)$ mentioned whole-class discussions, in addition to $40(50 \%)$ who referred to small-group discussions. The validity of this evidence is weaker, as it was asked in a quiz where names were provided. However 63 out of 83, as an overriding majority, can be argued to be quite strong evidence.

Finally, another indicator of student responses to discussions and ICP comes from the institutional course evaluations done at the end of semesters conducted by the university administration and posted on the web site of the university, available to the public since Spring 2003. The relevant two questions from student evaluations for our classes are extracted in Table 2.

Both of these questions are in the sub-section where students evaluate the effectiveness of the instructor on a five-point Likert scale ( $5=$ 'strongly agree'; $1=$ 'strongly disagree'). Sections (02, 04 etc.) are the various classes of the same course Zeynep taught and the numbers show the average student evaluations. There are significant positive differences between Zeynep's undergraduate course evaluations, department ('Dept average'), and firstand second-year (' $1 \& 2$ MAN') averages. Dannelle's course evaluations are positive too, but there are not any significant differences between hers and the department averages. This may be the result of policies and practices of the Graduate School of Education that emphasise student participation. We believe that our use of written ICP criteria and student-centred class activities are one reason for positive student course evaluations. The validity of these results is quite strong. The university administration conducts and uses the course evaluations as a part of the faculty performance assessment system. It is administered by a designated student without any instructor involvement and no student names are given. Students are constantly encouraged to provide honest and reliable feedback. One possible drawback is that course evaluations are administered for all courses at the end of the term, and students might not take them seriously after they evaluate several courses. 
Table 2. Student course evaluation results extracted from the university official web site (http://stars.bilkent.edu.tr) ${ }^{\mathrm{a}}$

\begin{tabular}{lcc}
\hline & Question $2^{\mathrm{b}}$ & Question $3^{\mathrm{c}}$ \\
\hline Zeynep's classes $^{\mathrm{d}}$ & & \\
Fall 2000 & & 3.97 \\
Section 02 & 4.75 & 4.03 \\
Section 04 & 4.79 & 3.55 \\
1\&2 MAN & 3.58 & 3.86 \\
Dept average & 3.88 & 3.93 \\
Fall 2001 & & 4.45 \\
Section 02 & 3.93 & 4.86 \\
Section 04 & 4.45 & 4.15 \\
Section 05 & 4.77 & 3.75 \\
Section 06 & 3.95 & 3.88 \\
1\&2 MAN & 3.81 & \\
Dept average & 3.94 & 4.81 \\
Fall 2002 & & 4.78 \\
Section 02 & 4.81 & 4.57 \\
Section 04 & 4.72 & 4.26 \\
Section 05 & 4.43 & 4.18 \\
Section 06 & 4.22 & 3.99 \\
1\&2 MAN & 4.27 & 4.52 \\
Dept average & 4.09 & 4.54 \\
Dannelle's class & & \\
Fall 2001 & 4.62 & \\
Dept average & 4.52 & \\
\hline Sincer & & \\
\hline
\end{tabular}

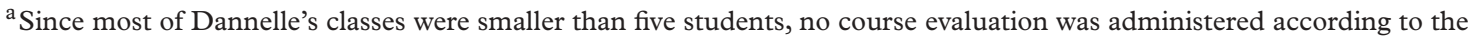
university policy.

${ }^{\mathrm{b}}$ Question 2: '[the instructor] stimulates interest in the subject'.

'Question 3: ' [the instructor] stimulates and directs in-class student participation effectively'.

${ }^{\mathrm{d}}$ See text for an explanation of Zeynep's classes.

$5=$ 'strongly agree'; $1=$ 'strongly disagree'.

\section{Limitations}

All is not a bed of roses, however. There are also some thorns in the bushes. Firstly, there are problems with preparing and using the written criteria sheets. It takes time to prepare them. The descriptors may be confusing to students; therefore, the instructors may have to spend class time explaining the meaning of these criteria. In addition, as in Zeynep's case, students may feel that a written description is useless and childish.

Secondly, another thorn is about creating and maintaining this active learning environment. It might be too risky for some professors, as in student-centred classrooms the professor has less 
control over the outcomes and students have more. The professor may not be able to cover the content to the extent that $\mathrm{s} /$ he would without discussion. S/he may have students say things that hurt each other. S/he may just lose control of the class with many side conversations and no focus of student attention on the discussion (Brookfield \& Preskill, 1999).

Thirdly, although evidence is found for student preference for more student-centred classrooms (Williams, 1992), there are still some students who do not like to participate actively. Especially in the Turkish case, as already argued above, students are accustomed to the transmission view of teaching and learning, i.e. lectures, memorisation of knowledge, instructors as the single authority. When faced with student-centred classrooms, some students may feel and fear that they do not 'learn' as much.

Finally, just preparing and discussing written criteria sheets that lay out our expectations is not enough. Students are still concerned about how they are graded. Acting on feedback from students and colleagues, we have now added the levels of performance as an assessment scale to our criteria sheet (Figure 4).

\section{Conclusion}

The purpose of this paper is to share our experience of incorporating a written description of ICP in a student-centred classroom. We hoped that by being more explicit with our expectations we could signal to students that we were quite serious about their participation, therefore they would participate more. Although we had some resistance at the beginning, the majority of our students valued the discussions and student-centred classrooms, as indicated in course evaluations.

Evaluation of ICP according to the above criteria:

High level of ICP:

15 points: consistent, positive, open to learning, risk-taker, always attends class (on time), prepares for and participates in discussions, has a 'CAN-DO' attitude.

Mid level ICP:

10 points: consistent most of the time, usually positive, misses five classes at most, is usually prepared for class and participates in discussions.

Low level ICP:

5 points: not willing to take risks, complains and sits back most of the time, does not do the preparations for class, hardly participates in any class activity.

Lowest level ICP:

0-4 points: unwilling to try new ideas, watches the clock, looks bored during classes, is often late or does not attend majority of the classes, unprepared when attends, has a 'CAN'T-DO' attitude.

Figure 4. Assessment of in-class participation according to the written criteria 
An important part of our work is its location, Turkey, a transnational society with a young democracy. It is especially important to use student-centred activities in this context, where the transmission model of teaching largely prevails, to foster participation, a foundational disposition for democratic citizenship.

A residual benefit to us is that we learned implementing new practices, as in the other aspects of teaching, benefits from reflection and collaboration, and ultimately leads to more adventurous teaching (Cohen, 1988).

\section{Acknowledgement}

This paper is derived from an action research project supported by the Teaching Development Grant Programme of Bilkent University, Ankara, Turkey.

\section{Notes on contributors}

Kadire Zeynep Girgin is a lecturer in the Faculty of Business Administration at Bilkent University, Ankara, Turkey. She received her MA in Training and Human Resource Development from the University of Warwick, UK. Her research interests include scholarship of teaching, reflective practice and human resource management. She continues her Ph.D. at the Business School of De Montfort University and her research is on the human resource management policies and practices of American multinationals in Turkey.

Dannelle D. Stevens was a visiting Associate Professor at Bilkent University, Ankara, Turkey during 2000-2002 in the Graduate School of Education. Now she is at Portland State University, Oregon, USA. Her research interests include scholarship of teaching, action research, classroom assessment and the processes that facilitate school-university partnerships. She is interested in the processes that facilitate the bridging of cultures in classrooms, schools and communities. To this end she has taught in Turkey, Thailand and Brazil and conducted research in Japan.

\section{References}

Angelo, T. A. (1999) Doing assessment as if learning mattered most, American Association of Higher Education Bulletin. Available online at: http://www.aahe.org/Bulletin/amgelomay99.htm (accessed May 1999).

Biggs, J. (1999) Teaching for quality learning at university: what the student does (Buckingham, Open University Press).

Boud, D. (1990) Assessment and the promotion of academic values, Studies in Higher Education, 15(1), 101-113.

Brookfield, S. D. \& Preskill, S. (1999) Discussion as a way of teaching: tools and techniques for a democratic classroom (San Francisco, CA, Jossey-Bass).

Brooks, J. (1990) Teachers and students: constructivists forging connections, Educational Leadership, 47(5), $68-71$.

Brown, S., Rust, C. \& Gibbs, G. (1994) Strategies for diversifying assessment in higher education (Oxford, Oxford Centre for Staff Development). Excerpts available online at: www.lgu.ac.uk/deliberations/ocsd-pubs/divass2.html (accessed September 2000).

Burns, J., Clift, J. \& Duncan, J. (1991) Understanding of understanding: implications for learning and teaching, British Fournal of Educational Psychology, 61(3), 276-290. 
Cohen, D. (1988) Teaching practice: plus change... Issue Paper 88-3 (East Lansing, MI, National Center for Research on Teacher Education) (ED299257).

Dole, J. \& Sinatra, G. (1998) Reconceptualizing change in the cognitive construction of knowledge, Educational Psychologist, 33(2/3), 109-128.

Elton, L. \& Laurillard, D. M. (1979) Trends in research on student learning, Studies in Higher Education, 4, $87-102$.

Finkel, D. L. (2000) Teaching with your mouth shut (Portsmouth, NH, Heinemann).

Good, T. L. \& Brophy, J. (1995) Educational psychology (White Plains, NY, Longman).

Günçer, B. (1998) Restructuring of teacher education programs in faculties of education (Ankara, Council of Higher Education).

Ramsden, P. (1988) Studying learning, improving learning, in: P. Ramsden (Ed.) Improving learning: new perspectives (London, Kogan Page).

Stevens, D. D. \& Girgin, K. Z. (2001) Assessment with a twist: in-class participation in a Turkish university classroom, Faculty Focus, 10(1), 11-12.

Stevens, D. D. \& Girgin, K. Z. (2002) Traditional Turkish school practices, university teaching innovations: potent mix for building social capital and real lifelong learning?, paper presented at the British Association of International and Comparative Education (BAICE) Conference, Nottingham, 6-8 September.

Williams, E. (1992) Student attitudes towards approaches to learning and assessment, Assessment and Evaluation in Higher Education, 17(1), 45-59. 